\title{
VERGÍLIO FERREIRA E A FENOMENOLOGIA
}

\section{Hélder Godinho}

Faculdade de Ciências Sociais e Humanas

Universidade Nova de Lisboa

Vergílio Ferreira só tarde chegou à Literatura e ao pensamento em geral, como ele próprio o esclarece, devido à educação estrita que teve nos anos de Seminário, em que o conhecimento era orientado para os fins religiosos. De modo que só chegou definitivamente à Literatura por volta dos anos 40, como afirma em "Um Escritor Apresenta-se", 1 datando o seu primeiro romance, O Caminho Fica Longe, ${ }^{2}$ de 1939 (embora só publicado em 1943), tendo os seus primeiros contactos com o romance sido através de Eça e dos brasileiros (Erico Veríssimo, Jorge Amado, Lins do Rego, entre outros) e dos norte-americanos por eles traduzidos, como Faulkner e Steinbeck. ${ }^{3}$ Nessa época, entre a Presença e o neo-realismo (oscilação que marca o seu primeiro romance), a força do neo-realismo acabará por o conquistar na última

${ }^{1}$ Espaço do Invisivel 4. Lisboa: Bertrand, 1995, pp. 15-39, p. 21, por exemplo. Este título foi usado por Maria da Glória Padrão para a coletânea de entrevistas que organizou e que cito adiante.

2 Lisboa, Inquérito, 1943.

3 Vd. "Para uma auto análise literária". Espaço do Invisivel 2. Lisboa: Arcádia, 1976, pp. 9-19, p. 12; ou Um Escritor Apresenta-se, apresentação, prefácio e notas de Maria da Glória Padrão. Lisboa: Imprensa Nacional-Casa da Moeda, 1981, p. 30.

Phainomenon, n. ${ }^{\circ}$ 22-23, Lisboa, pp. 345-372

DOI: $10.2478 /$ phainomenon-2011-0017

(C) 2011 Godinho. This is an open access article licensed under the Creative Commons Attribution-

NonCommercial-NoDerivs License (http://creativecommons.org/licenses/by-nc-nd/3.0/). 
parte desse romance, mantendo-se os dois seguintes, Onde Tudo Foi Morrendo ${ }^{4}$ e Vagão $J,{ }^{5}$ na mesma linha.

A relação de Vergílio Ferreira com o neo-realismo foi sempre "infeliz" para o autor, porque a temática social "era descritiva e limitada, esquecia-se um pouco do destino do próprio artista e desenvolvia-se de algum modo à superficie da vida. [...] A uma temática de algum modo circunstancial, eu vim assim a preferir uma mais duradoira, a um problema imediato, eu antepus um questionar que lhe subjazia, a uma questionação sobre problemas digamos "práticos", eu preferi a defrontação do homem com a sua própria condição". ${ }^{6}$ Passará, então, via Hegel, para a questionação existencial.

E aqui é interessante ver como Vergílio Ferreira descreve e interpreta essa passagem. Entre Vagão $J$ e Mudança, ${ }^{7}$ leu $A$ Fenomenologia do Espirito de Hegel e $O$ Ser e o Nada de Sartre, como refere em vários lugares. Em "Para uma autoanálise literária", explica que o pantragismo hegeliano da "consciência infeliz" se cruzou com o existencialismo de Sartre, resultando, em Mudança, no conflito entre o absoluto e o relativo, "a questão de um valor que à vida ordenasse". ${ }^{8} \mathrm{E}$ acrescenta que o cartesianismo de Sartre nunca o "entusiasmou muito. Mais do que uma discussão teórica da "liberdade", importava-me o problema de lhe dar um destino, o interrogar-me sobre o "para quê" do próprio homem. Assim, me interessou mais um Camus, ou um Jaspers, ou um Heidegger da 1. a fase, e acessoriamente, um Kierkegaard". 9

Este texto, que foi uma conferência feita em Salamanca em 1972, explica assim a sua evolução, sem referir a Fenomenologia explicitamente. Mas, no já referido "Um escritor apresenta-se", texto que "serviu de base a conferências pronunciadas em Madrid, Assis (Brasil) e Copenhaga", ${ }^{10}$ e que é posterior, explica que se interessou pela literatura por causa da "palavra", porque "na "palavra" eu podia aliar a emoção que nos abala à "ideia" que se quer exprimir". ${ }^{11} \mathrm{E}$, depois de referir a estreiteza do ideário neo-realista e a adesão ao romance-problema e à questionação existencial e de fazer uma sua integração mais larga na cultura europeia, reflete sobre o passado e afirma, sem

\footnotetext{
${ }^{4}$ Coimbra: Coimbra Editora, 1944.

${ }^{5}$ Coimbra: Coimbra Editora, 1946.

6 Um Escritor Apresenta-se, ed. cit., p. 25.

${ }^{7}$ Lisboa: Portugália, s.d. (1949).

8 O.c., p. 14.

9 O.c., p. 15.

10 O.c., p. 15.

11 O.c., p. 20.
} 
se deter nas obras de Hegel e Sartre, que, no entanto, foram a charneira para a sua mudança:

Naturalmente, e como disse, tudo isto me escapa a uma atenção consciente. É retornando a mim e observando certos efeitos como "crítico", é ouvindo mesmo as observações de alguns leitores, é analisando mesmo em obras minhas antigas a procura de certos resultados, é assim que eu determino o meu propósito de os conseguir. Mas convergentemente (e não porque daí partisse) penso hoje que a fenomenologia, outrora muito no centro dos meus interesses, terá não digo contribuído para as minhas tentativas, mas legitimado ou dado um certo fundamento. Decerto tem-se ligado a fenomenologia a pesquisas de sinal oposto, nomeadamente as do "novo romance" na sua fase objetivista ou objetal. Nesse caso e noutros, com efeito, nós encontramos o mesmo propósito de descritivismo, anotação fria do que caracteriza os objetos na sua independência exterior. Mas segundo o princípio da "intencionalidade", esse que diz que ter consciência é ter consciência de alguma coisa (como ter um sentimento é referi-lo a alguma coisa), eu creio que a íntima união do pensante e do pensado, do eu e do objeto, fala de algum modo ao meu propósito de não me distanciar de nada a que me reporte, favorece teoricamente esse desejo de fixar na sua intensa flagrância aquilo que me emocionou. ${ }^{12}$

Vemos assim que a continuação das leituras filosóficas que se seguiram aos dois livros referidos, e que foram fundamentais para a mudança de rumo na prática literária e no pensamento de Vergílio Ferreira, ficaram marcadas pela fenomenologia, cujas relações com Hegel (para não falar de Sartre, evidentemente) Vergílio Ferreira fará questão de sublinhar, assunto a que voltarei. E num estudo especificamente dedicado a Husserl, "Do indivíduo à História - Husserl" refere que a problemática de Estrela Polar das relações eu/tu está diretamente ligada à questão da intersubjetividade posta por Husserl na Quinta Meditação Cartesiana. ${ }^{13} \mathrm{O}$ que não quer dizer que essa convergência signifique influência direta, que é sempre difícil de estabelecer não só porque seria necessário conhecer as datas das leituras como também porque os problemas nascem de um resíduo de leituras diversas. De resto, Sartre também se liga à forma como Estrela Polar ${ }^{14}$ tratou esse assunto: "Porque não há uma união senão perante um terceiro. Sartre o frisa na sua Dialética" ${ }^{15}$

Além disso, há, em cada um de nós, uma predisposição, sobre que Vergílio Ferreira insiste, para determinados problemas ou filosofias, de que falarei mais adiante. Não deixa de ser curioso que Vergílio Ferreira tenha dito que o seu primeiro romance, O Caminho Fica Longe, escrito em 1939, quando ainda

12 O.c., pp. 34-35.

13 Espaço do Invisivel 4, ed. cit., pp. 291-316, p. 305.

14 Lisboa: Portugália, s.d. (1962).

15 Um Escritor Apresenta-se, ed. cit., p. 52. 
não tinha lido os filósofos que o viriam a marcar, era já um romance existencialista:

As minhas relações com o existencialismo já vêm de longa data. O meu primeiro romance, escrito há uns vinte e tantos anos, ou seja, quando eu ignorava tal corrente, tem já que ver com essa doutrina. ${ }^{16}$

De facto, embora, como disse atrás, seja um romance inserido na sua fase neo-realista, essa inserção deriva apenas, nesse romance, de uma evolução interna em que o narrador acaba por se ligar a uma problemática social por abdicação da sua vida pessoal e afetiva. Mas todo o percurso que a isso conduz implica uma questionação sobre o próprio, o outro, a significação da vida, o escrever como substituição da presença ausente, temas que se integram numa questionação que Vergílio Ferreira liga ao existencialismo, algumas linhas a seguir:

Fundamentalmente, o que no existencialismo me interessa é o meu interesse pelo homem-problema e o que num domínio profundo se exprime pela interrogação. ${ }^{17}$

Além disso, Apariçãao ${ }^{18}$ é um romance em que Delfim Santos aponta uma decisiva influência de Jaspers quando Vergílio Ferreira ainda o não tinha lido, ${ }^{19}$ o que mostra que as influências têm não só a ver com o ambiente cultural do autor como um todo, como também com as suas predisposições internas fixadas numa forma interior, assunto a que voltaremos.

Mas retomemos Hegel e a importância que teve em Vergílio Ferreira. Numa entrevista recolhida por Maria da Glória Padrão na já referida coletânea, diz:

Demorava tempo a explicar-lhe como se pode passar de um Hegel para o existencialismo. Mas passa-se perfeitamente. De resto, hoje Hegel é dado, por M. Ponty, como um dos antecessores do existencialismo. [...] Certamente que V. conhece do Hegel a famosa tese, antítese e sintese, a afirmação de que a verdade se vai construindo com vistas a um absoluto em que haverá uma total união desse absoluto consigo próprio, etc. Daqui se deriva facilmente para uma conceção do que há de transitório numa verdade absoluta, ou seja, daqui se deriva

${ }^{16}$ Ibid., p. 172.

17 Ibid., p. 172. Sobre $O$ Caminho Fica Longe que, apesar de ser o primeiro romance, é muito importante para a compreensão do que será a obra futura de Vergílio Ferreira, vd. o meu estudo "O amor da personagem fraturada em $O$ Caminho Fica Longe de Vergílio Ferreira". In: Giorgio de Marchis et al., Criação e Critica. Homenagem de 8 poetas e 8 ensaistas a Giulia Lanciani. Lisboa: Caminho, 2003, pp. 85-93.

18 Lisboa: Portugália, s.d. (1959).

19 Um Escritor Apresenta-se, ed. cit., pp. 231 e 265. 
para a conceção de que todo o absoluto é relativo. Na realidade, essa conceção tem grandes afinidades com uma problemática existencialista. ${ }^{20}$

E, na entrevista dada a Diogo Pires Aurélio, no jornal República de 16 de agosto de 1973 e inserida na totalidade em Apêndice na coletânea de M. Glória Padrão, afirma com clareza:

Devo dizer-lhe que sou genericamente um hegeliano, como praticamente sempre fui. Fui para Hegel através de Marx e posso dizer que regressei a Marx também com Hegel, formando todo um circuito. Passei de Hegel ao existencialismo fundamentalmente através da consciência infeliz, que é a consciência das contradições e genericamente não saí ainda de lá. Embora o hegelianismo me sirva fundamentalmente para a determinação de um estado de coisas mais exterior a mim do que pessoal, visto que os problemas pessoais foi sobretudo através do existencialismo que eu os pude estabelecer e discutir. ${ }^{21}$

Como já notámos, o romance de mudança do neo-realismo para a problemática de tipo existencial que marcará toda a obra de Vergílio Ferreira, e que se intitulou justamente $M u d a n c ̧ a,{ }^{22}$ é fundamentalmente um romance hegeliano, como Pires Aurélio refere, que foi lido em geral como existencialista, o que Vergílio Ferreira justifica invocando de novo a consciência infeliz. Mas, mais importante é o facto, que o entrevistador nota, de que toda a obra de Vergílio Ferreira, a começar nos romances neo-realistas, tem uma unidade, para além da mudança que Mudança traz, que lhe é dada por uma consciência infeliz que, como afirma Diogo Pires Aurélio, "ora se vê a braços com problemas de tipo hegeliano-marxista, como lhe chamou (nós chamar-lhe-íamos simplesmente neo-realistas), ora com problemas de tipo existencialista". ${ }^{23}$ Ao que Vergílio Ferreira responde, concordando, e explicando que, em qualquer dos casos, está em jogo uma "redenção do homem" que, a princípio, foi situada no domínio socioeconómico mas cuja linha de continuidade é uma linha humanista.

Esta continuidade parece-me importante porque, por debaixo de realizações romanescas tão diversas, mostra uma mesma Forma interior que, lida mais em pormenor, começa nos próprios poemas de juventude, começados a escrever por volta dos 12 anos. Trata-se de uma "história", que funciona como mito

20 Ibid., p. 231.

21 Ibid., p. 389.

22 Na realidade, antes de Mudança, Vergilio Ferreira escreveu A Promessa, romance que não chegou a publicar. $E$, igualmente, um romance hegeliano, que foi recentemente editado por Fernanda Irene Fonseca e por mim próprio: Ferreira, Vergílio, Promessa. Romance inédito (1947), edição de Fernanda Irene Fonseca e Hélder Godinho. Lisboa: Quetzal, 2010.

23 Ibid., p. 403. 
condutor de toda a obra, e que está sempre presente, embora com valorizações diversas dos seus elementos (dos seus "mitemas"), que desenvolverei adiante.

\section{II}

Façamos um rápido percurso pela obra de Vergílio Ferreira. Desde o primeiro romance - e mesmo já nos poemas de juventude - se reconhece o que será a problemática persistente de Vergílio Ferreira, para além das fases literárias e ideológicas que é costume apontar-lhe. Mas, como notou Diogo Pires Aurélio na entrevista acima referida, há uma continuidade, naquele caso da fase neo-realista até Mudança, continuidade que se manterá até ao fim da sua obra, por virtude do que chamei o "mito estilo", a narrativa fundadora que percorre toda a obra de Vergílio Ferreira.

No primeiro romance, $O$ Caminho Fica Longe, toda a ação se passa em torno de personagens não plenas, que andam dispersas pelos outros, como é dito a propósito da personagem principal masculina. De tal modo que uma das personagens femininas namora dois rapazes que se completam simbolicamente mas apenas namorou $u m$, eles são a mesma personagem masculina compósita.

Neste romance, supostamente neo-realista, pelo menos na sua parte final, encontramos, assim, toda uma questionação sobre a identidade. ${ }^{24} \mathrm{Em}$ Vagão $J$, que Vergílio Ferreira republicou em vida, a questão da identidade é curiosamente ligada à ignorância, que impede a descodificação do mundo ao ponto de os pobres não perceberem algumas formas de opressão e a sua posição nelas e de terem dificuldade em amar e não saberem dizer as palavras certas na relação de amor. A grande diferença entre os pobres e os ricos não é que os pobres sejam melhores que os ricos que os oprimem, a grande diferença é que os pobres não sabem descodificar o mundo e a sociedade, nem os seus sentimentos. Ficam assim fechados num universo restrito, porque o não conhecimento da geometria significativa da sociedade e do mundo os impede de encontrarem o seu lugar e o outro. A única relação que conseguem com o mundo é aquilo que aprenderam com os ricos: a violência, e, quando se trata de sobrevier, a denúncia falsa de um outro pobre como eles. A falta de conhecimento implica a não-relação com o mundo. Precisam de um iniciador que lhes faça conhecer algumas verdades para se redimirem socialmente - e aqui a importância e função do agitador e do professor que, no entanto, se sente impotente para desempenhar essa função.

${ }^{24} \mathrm{Vd}$. o meu estudo, já citado, "O amor da personagem fraturada em $O$ Caminho Fica Longe de Vergílio Ferreira". 
Falta-lhes, assim, um elemento de ligação para o conhecimento, falta que redobra a falta da personagem pai enquanto indicador de um caminho. Já em $O$ Caminho Fica Longe o pai era negativo na medida em que não apoiava os sacrifícios da mãe para a promoção social do filho. De seguida, no segundo romance, anterior a Vagão J, Onde Tudo Foi Morrendo, é a morte (ausência) do pai que provoca a derrocada do conforto material da família. Agora em Vagão $J$, a doença do pai, num acidente de trabalho que ficou mal resolvido devido ao desinteresse da classe patronal, aumenta as dificuldades da família em sobreviver. Também em Estrela Polar o pai é desvalorizado ao ponto de talvez não ser o verdadeiro pai, em Mudança o pai suicida-se complicando, pelo menos, a vida psicológica do filho, no conto "A estrela" ${ }^{25}$ provoca mesmo a morte do filho ao obrigá-lo a ir repor a estrela no céu. Não vale a pena continuar a enumeração, lembraria apenas que Eduardo Lourenço, na sua comunicação ao Colóquio de homenagem a Vergílio Ferreira que a Inova realizou no Porto em julho de 1977, refere a persistência da morte dos pais em vários romances de Vergílio Ferreira, "como se o "herói" só possa nascer enquanto inscrito e revelado por esse primeiro tremor de terra absoluto que é a morte dos pais". ${ }^{26}$ e eu acrescentaria que o pai, quando não morre ou está ausente, é desvalorizado, o que não acontece com a mãe.

Isto é importante porque já nos poemas de juventude essa situação aparece, tendo o pai faltado à sua função fundamental de indicar o caminho: "meu filho, eis aqui o teu trilho". De facto, o jovem poeta encontra-se separado da verdadeira vida, que os outros têm, porque está desterrado num mundo deserto, o que significa não só sem a presença dos outros com quem o poeta se pudesse relacionar (os seres que encontra estão longe dele, não participam da sua natureza de poeta), aparecendo a sua verdadeira pátria num além longínquo, que virá a ser significado pela estrela e a sua condição de desterrado é devida à falta de iniciador que mostre o caminho para a sua verdadeira pátria e origem. Há, assim, este núcleo significativo muito arcaico no percurso do que chamei a arquipersonagem vergiliana e que causa o que também chamei uma Disjunção fundamental entre as personagens que conduzem a ação e a sua origem, distância essa que é responsável também pela separação de si a si provocada pela Disjunção/ausência. ${ }^{27} \mathrm{~A}$ arquipersonagem precisa de se encontrar e, para isso, precisa de encontrar a sua pátria distante onde o outro que lhe falta (a Presença ausente) o reconheceria promovendo o encontro com a sua

25 Contos. Lisboa: Arcádia, 1976.

26 Vd. Estudos sobre Vergílio Ferreira, organização e prefácio de Helder Godinho. Lisboa: Imprensa Nacional-Casa da Moeda, 1982, p. 384.

$27 \mathrm{Vd}$. O Universo Imaginário de Vergílio Ferreira. Lisboa: Imprensa Nacional-Casa da Moeda, 1985. 
identidade, atualmente fraturada, como aparecia consciente e explicitamente dito em $O$ Caminho Fica Longe: "E Rui tinha pena de se ver assim repartido por toda a gente, com um bocado de si em cada canto". ${ }^{28} \mathrm{~A}$ arquipersonagem vergiliana é, assim, alguém que espera vir a encontrar-se consigo e com a sua radicalidade identitária num futuro. Para que isso seja possível, necessita do conhecimento do caminho, que, como em Vagão $J$, está ligado ao conhecimento em geral que abolirá a alienação e fará encontrar o outro de que precisa para a sua unificação identitária, de que $O$ Caminho Fica Longe tem consciência:

Corria-lhe assim a vida triste e estéril, porque ninguém o olhava de modo a fazer-lhe sentir que ele era uma realidade. [...] Mas se Joana o aceitasse, Rui sentiria o sabor gostoso de uma conquista. Ele valia alguma coisa. ${ }^{29}$

Mas, como esse reconhecimento de que a arquipersonagem necessita, no limite, implicaria encontrar a Presença que está ausente deste mundo disjuntado da origem e que habita um além universal (Presença cujo sentido oscila entra a mulher fundamental e a divindade), esse encontro e essa identidade que levaria a arquipersonagem a uma fusão com o universo (como vai acontecer em Em Nome da Terra $)^{30}$ ficam inexoravelmente adiados para um futuro que é preciso conquistar pelo conhecimento e recuperação idealizante do outro, como na mulher morta de Em Nome da Terra.

Convém notar que a aparição de si a si (que dá a visão do eu metafísico) é, ainda, uma descoberta em solidão, em que o único outro é a imagem do próprio no espelho. A consciência disso e a necessidade de prosseguir a procura eterna do Amor/Conhecimento ("Porque o amor aparece como a verdade, e com ela se gasta, se destrói", dirá em Estrela Polar. ${ }^{31}$ E em Pensar: "A verdade é amor - escrevi um dia. Porque toda a relação com o mundo se funda na sensibilidade, como se aprendeu na infância e não mais se pôde esquecer.") $)^{32}$ fá-lo-ão continuar a procurar o Outro, mesmo quando as mulheres amadas são rigorosamente iguais, como em Estrela Polar.

$E$ aqui convém retomar o percurso pelos romances que se seguiram a Vagão $J$, e que manifestam uma mudança quando a problemática vergiliana encontra um suporte filosófico nas leituras de Hegel e Sartre, entre Vagão $J$

28 O.c.,p. 271.

29 O.c., p. 278.

30 Lisboa: Bertrand, 1990.

31 O.c., p. 43.

32 Pensar: Lisboa: Bertrand, 1992, p. 12. A identidade da verdade e do amor tem, assim, que ver com a importância do sentimento, tão acentuada por Vergilio Ferreira, para o existencialismo. 
e Mudança, que foram completadas posteriormente com Heidegger, Husserl, Jaspers (mais tarde), Kierkegaard também, para falar apenas dos filósofos que o próprio Vergílio Ferreira costumava apontar como aqueles que mais o influenciaram. Curiosamente, Husserl não costuma aparecer nessa lista, embora no estudo que atrás citei, "Um Escritor Apresenta-se", refira a grande importância da fenomenologia na sua problemática, para além da fenomenologia existencial que começou por beber em Sartre, e a Husserl dedique todo o estudo, já mencionado, "Do indivíduo à História - Husserl”. Para já não falar do estudo introdutório a $O$ Existencialismo é um Humanismo, ${ }^{33}$ e da implicação da fenomenologia no existencialismo.

No romance Aparição, Vergílio Ferreira trata daquilo que será sempre um dos seus temas fundamentais, a aparição de si a si próprio, a descoberta daquela zona radical de si a que chamará o eu metafísico e que, em alguns escritos, parece ligar a Jaspers, mas que não pode deixar de ter a ver com o eu puro de Husserl nem com Sartre. No referido "Da Fenomenologia a Sartre", escreve: "um Jaspers [...] fixa-se predominantemente no "eu", mas numa sua voz metafisica". ${ }^{34}$ Em "Vida, Arte", inserido em Espaço do Invisivel 1, diz:

Vivemos em "situação", sabemo-lo até à evidência. Mas desse todo unificado que somos nós e o mundo, a dominante não está em nós: um "eu puro" não tem conteúdo, ensina-nos a fenomenologia. Ele é assim uma ficção, se o tomamos como estrita realidade independente, fechada em si, ao modo da realidade objetiva (embora, ao que penso, algo fale nele quando a ele nos remetemos e o deixamos aparecer): o que nele fundamentalmente podemos analisar é o seu comportamento nas relações com o mundo. ${ }^{35}$

E, de novo, no estudo anterior:

Como na consciência sartreana que é, em jogo de espelhos, refletida-refletora, mas com a original emoção que supera ou antecede o saber, no "eu" originário ou original que se ergue ante nós, de nós irrompe brutalmente, iluminadamente, nós estamos e não estamos co-presentes, nós surpreendemos num ápice que se desfaz a irrupção de algo estranho e medonho e simultaneamente nos sentimos sendo isso que de nós irrompe. ${ }^{36}$

Mas a aparição de que eu falo é o puro surgimento de mim a mim, não de um ser opaco ou substancializado ou "psíquico", mas do puro ser vivo, subitamente erguido à minha frente, separado de mim enquanto precisamente vivo e penso; e se a individualização de um "eu" implica o "outro", negando-o, a verdade é

33 "Da Fenomenologia a Sartre", introdução a O Existencialismo é um Humanismo. Lisboa: Presença, 3." edição revista, s.d.

${ }^{34}$ Ibid., pp. 55-56.

35 Lisboa; Portugália, 1965, pp. 33-41, p. 33.

36 "Da Fenomenologia a Sartre", cit., p. 92. 
que na afirmação irrecusável de quem somos estamos falando de algo que de certo modo nos transcende, sendo nós e por transposição (não por contraste) os outros. Adaptando e apropriando-nos do pensamento de Sartre [...] nós poderíamos dizer que o nosso "eu" se determina por uma presença-ausente. ${ }^{37}$

O conteúdo de um conceito usado por um autor é normalmente fruto de uma súmula pessoal e raramente é importação direta de um outro autor. No caso deste conceito fundamental em Vergílio Ferreira, convém ainda lembrar que o "espanto" da descoberta de si, até porque um "si" não está desligado dos outros e do mundo, é também o espanto que leva ao filosofar:

[...] o "eu" original é pois, além da revelação do que sou e me espanta, e me intriga, a abertura da dimensão em que se revela o espanto de tudo, o insólito de tudo, a absoluta impossibilidade do que se me evidencia, me domina. ${ }^{38}$

O espanto que leva ao filosofar e ao desejo de fazer arte, como nota na entrevista a Diogo Pires Aurélio, leva ao desejo de atingir a essencialidade ou a origem da vida e, imbricadamente, a essencialidade de si. Uma análise (que não cabe aqui) do romance Aparição far-nos-ia perceber como essa aparição é o momento em que a indiferenciação da pertença a um Todo, fortemente ligado ao passado, se abre ao momento auroral da diferenciação de uma individualidade, numa síntese que equilibra o eu e o Todo, síntese que é, pela sua natureza, "instável" e, portanto, não pode permanecer, evoluindo obrigatoriamente para a "petrificação", como Vergílio Ferreira afirma. A estátua de Nítido Nulo ${ }^{39}$ erigida ao ideólogo da revolução simboliza a "petrificação" da pureza das ideias que a revolução pôs em marcha e que o novo regime traiu ao comportar-se como o anterior, sendo por isso dinamitada pelo próprio que nela estava representado - o que o levou à condenação à morte.

O facto, referido atrás pelo autor, de que o eu implica o tu, vai ser o tema fundamental de Estrela Polar. E aqui convém lembrar algumas reflexões de Vergílio Ferreira a propósito disso e da fenomenologia. Lembremos alguns aspetos do romance.

Em "Para uma autoanálise literária", diz:

Revertido o "eu" ao "tu", que é um "eu" objetivado, fascinou-me o problema da comunicação - e dele falei em Estrela Polar. O limite impossível dessa comunicação determinei-o na impossibilidade de precisamente um "eu" ser um "tu", sermos nós nos outros, revivermos absurdamente nos outros o que vivemos em nós. Numa perspetiva de radicalidade, a comunicação era-me uma contradição. ${ }^{40}$

\footnotetext{
37 Ibid., p. 93.

${ }^{38}$ Ibid., p. 98.

39 Lisboa: Portugália, 1971.

${ }^{40}$ Espaço do Invisivel 2, ed. cit., pp. 9-19, pp. 16-17.
} 
Estrela Polar é um dos mais importantes romances de Vergílio Ferreira no que ao sentido da sua obra diz respeito e a sua problemática ultrapassa a questão do "tu". As gémeas que o narrador ama sucessivamente, porque a primeira se lhe gastou, apesar de serem absolutamente iguais, têm a ver não só com a questão da identidade do outro, onde se insere toda a questionação sobre quem ele é na radicalidade do seu eu metafísico, de que o narrador de Aparição fizera a experiência, como também - e isto é fundamental - com a procura de um Outro ausente, a que tenho chamado Presença ausente, e que é uma entidade complexa mas que representa, na sua significação mais persistente, a Face amável que a arquipersonagem espera um dia encontrar, e o Saber sobre a "Máquina do Mundo", porque o amor e o saber estão ligados, como já referimos. Assim, amar sucessivamente as gémeas, tão iguais que está casado com uma julgando que ela é a outra, mas de quem se vai separar ao saber quem é, põe a questão da identidade do Outro: "Quem estava lá? Quem eram?", interroga-se o narrador ao sair de um serão em casa das gémeas. ${ }^{41}$

Esta questão liga-se, também, ao desgaste do interesse pelo outro (outra, neste caso) porque o outro a amar não é uma presença plena mas apenas uma encarnação ocasional, até se desgastar, dessa Presença distante. Ao arrastar Aida até ao cimo do outeiro, grita o nome dela para a distância, ${ }^{42} \mathrm{e}$, mais tarde, ela dir-lhe-á: "Tu casas quando me encontrares". ${ }^{43} \mathrm{Na}$ medida em que é a Presença ausente que o narrador pretende encontrar nas gémeas, ela é o terceiro que permite o encontro de dois seres em si incomunicáveis. Na segunda edição do romance, vem uma epígrafe de Pierre Emmanuel que diz: "Toda a relação erótica é uma relação a três em que o absoluto é um dos partenaires". ${ }^{44}$ Esse outro radical e ausente em si, apenas temporalmente encarnado nas mulheres que o vão representando, conota-se também, além da procura necessariamente imparável da Face final, do outro aspeto da Presença, o Absoluto, ${ }^{45}$ com cuja união o eu e o tu se uniriam na origem de ambos, origem que é radicalidade de ser e passado primordial, com o carácter fusional que já encontrámos em Aparição. O encontro desse Outro radical (o terceiro entre) levaria ao encontro com o outro humano amado e ao fim do que chamei a Disjunção Fundamental, como nos mostram as belíssimas páginas finais de Em Nome da Terra, onde a mulher morta é recriada pela escrita no seu eu metafísico, "puro", levando a relação com ela, agora essencializada, à abolição de todas

\footnotetext{
41 O.c., p. 76.

42 O.c., p. 37.

43 O.c., p. 49.

44 Lisboa: Portugália, 1967.

45 De algum modo, também, um nome do Ser heideggeriano.
} 
as disjunções e à fusão primordial com o universo, recuperado assim o Mundo Original a que a arte deve dar acesso:

E vão sendo horas enfim de descermos ao rio. Amanhã talvez? Hoje. Um dia. Estará uma noite quente, caminharemos de mãos dadas. $O$ anjo não virá, que teria lá que fazer? vamos sós. Não terei medo da tua presença com toda a sua força de me fazer ajoelhar. Olharei o teu corpo na sua transparência incorruptível. Sofrerei em mim a descarga do universo e não gritarei o teu nome. Porque estará em mim e eu hei-de sabê-lo. A areia brilhará de uma luz pálida, pisá-la-emos devagar a um impulso fortíssimo e lento. Estaremos nus desde o início, sem vergonha anterior. Nudez primitiva, não o saberemos. Porque será uma nudez para antes de os deuses nascerem. Então mergulharemos nas águas do rio e deitar-nos-emos na areia. E olharemos o céu limpo e sem estrelas. E acharemos perfeitamente natural, porque que a iluminação estará em nós. Erguer-nos-emos por fim e eu baixar-me-ei ao rio e trarei água na concha das mãos. E derramá-la-ei imensamente e devagar sobre a tua cabeça. E direi para toda a história futura, na eternidade de nós.

- Eu te batizo em nome da Terra, dos astros e da perfeição.

-E tu dirás está bem. ${ }^{46}$

De facto, o grande tema central de toda a obra de Vergilio Ferreira é a procura da origem, o que é patente não só na ficção como no ensaio. Invocação ao $\mathrm{Meu} \mathrm{Corpo}^{47}$ é um exemplo excelente disso, a que voltaremos.

Em Estrela Polar, essa solução "feliz" e final de Em Nome da Terra não se dá mas, mortas as duas gémeas, o narrador escreve da prisão olhando a estrela polar, símbolo dessa Presença ausente. ${ }^{48} \mathrm{~A}$ incomunicabilidade de dois eus tem, assim, a ver com a falta desse terceiro que, no entanto, une já o narrador e as gémeas na medida em que elas são amáveis enquanto representam a Presença, e esse é o tempo de duração do amor. Mas encontrá-la mantém-se como projeto de vida da arquipersonagem vergiliana ao longo de toda a sua obra, encontro que pararia a condição de sursis, de ek-sistência do homem vergiliano, fazendo coincidir o em-si e o para-si no encontro da origem. E essa é a função da arte, tantas vezes repetida, de dar acesso ao mundo original, recuperação do tempo e de si numa primordialidade atemporal e total. Encontrar essa Presença traria o encontro com o Outro e consigo mesmo.

A problemática de Estrela Polar é assim bem mais complexa que a simples questão da incomunicabilidade. Sobre ela, vejamos como Vergílio

${ }^{46}$ O.c., pp. 295-295.

${ }^{47}$ Lisboa: Portugália, 1969.

$48 \mathrm{Vd}$. o meu livro, atrás citado, O Universo Imaginánio de Vergilio Ferreira. 
Ferreira a liga à fenomenologia. Em "Do indivíduo à História - Husserl", Vergílio Ferreira diz a certa altura:

Curiosamente, não tentando Husserl a sondagem aprofundada de um "eu", dirse-ia suspeitar dessa vivência íntima de nós para nós, desse algo que nos vive, ao refletir sobre a intersubjetividade e nomeadamente sobre o "outro". Assim é no ego "que todo o alter ego, enquanto tal, recebe o seu sentido e valor". Ele fala-me a "uma relação original comigo que o experimento ou o tenho presente à consciência de qualquer outra maneira". Ele enfrenta-me "face a face" e "corporalmente," tal como eu o enfrento. Deste modo a relação mútua estabelece-se pela exterioridade e analogia, ela tem que ver apenas com uma dedução para o nosso juízo sobre o outro como para o juizo alheio sobre nós, remetendo o corpo e o psiquismo do outro para o nosso, como o nosso para ele. mas em dado momento Husserl desce mais fundo e interroga-se: "como entender essa constituição do novo sentido de ser, deste sentido: outro? Se já a auto constituição do ego, enquanto ser especializado, enquanto ser psicofisico, é um problema muito obscuro, neste caso trata-se de um problema ainda mais obscuro e uma questãoenigma francamente dolorosa essa de sabermos como no ego deve constituir-se um eu psicofisico diferente com um psiquismo diferente, visto que o sentido deste psiquismo, enquanto outro, implica a impossibilidade de princípio de que os elementos psíquicos constitutivos essencialmente próprios a este outro psiquismo eu os experimente numa verdadeira originalidade de modo semelhante àquela em que experimento os que me são próprios. Extraordinário enigma este, com efeito, fascinante impossibilidade de $e u$ ser um $t u$, de recuperar em mim a originalidade do sentir de outrem - e sobre isso se funda, permita-se-me, um romance a que dei o título de Estrela Polar... ${ }^{49}$

"Sobre isso se funda um romance a que dei o título de Estrela Polar". Mas isso não significa uma inspiração direta de Husserl mas apenas uma coincidência, creio. Porque, não só este problema se liga à Forma interna de toda a obra de Vergílio Ferreira, a que chamei "mito estilo", por ela ser o mito condutor específico, o autor interior de toda a obra, que é a marca (o estilo) de toda a sua significação (sobretudo na ligação à Presença ausente e a tudo o que ela implica), como também porque esta questão do eu e do tu está muito ligada no nosso autor a Sartre, nomeadamente às belas páginas que este lhe dedica em $L$ 'Etre et le Néant, no capítulo 'L'existence d'autrui”, onde, de resto, vai dialogar com Husserl, Hegel e Heidegger. ${ }^{50}$

Não deixa de ser interessante notar como Vergílio Ferreira oscila na conceção do eu - cuja defesa é um dos grandes temas da sua obra - entre a necessidade do outro para a sua existência e a iluminação de si, como se a necessidade

49 O.c., pp. 304-305.

so Sartre, L'Être et le Néant. Paris: Gallimard, 2004 [1943]. 
do outro para a própria iluminação de si, como vimos ele próprio afirmar, se subsumisse, por vezes, em algo muito próximo de uma substantivação de si:

Se Eva não existisse, não poderia Adão pensar "eu". Há quantos anos o escrevi. Mas volta-se agora a afirmá-lo como, aliás, o afirmou Buber antes da minha reflexão. Ao princípio era o "tu". E todavia não é verdade. Se o mundo fosse só amarelo, não saberíamos que era amarelo antes por exemplo de haver o azul. Mas vamos por isso dizer que primeiro existiu o azul? [...] Ao princípio era o "eu" e não o "tu". Mas sem o "tu" não poderíamos pensar o "eu".

Convém, neste momento, notar que a aparição de si a si que traz a visão do eu metafísico é a primeira certeza do percurso da arquipersonagem vergiliana. Com efeito, desde Mudança que as personagens se defrontavam com a mutabilidade de todos os valores e com a consequente dificuldade de assumirem uma identidade estável. São personagens que, de algum modo, dependem da situação para saberem quem são. Por exemplo, a personagem que conduz a ação, Carlos Bruno, começou por ser o filho de um rico industrial de lãs da Serra da Estrela que se casa com a filha do guarda-livros do pai, Berta. Com a crise e a falência do pai a que se seguiu o seu suicídio, Carlos tem que aprender a viver sem dinheiro, ou melhor, trabalhar como advogado para ter algum, sempre pouco, dinheiro. Ora, ele não sabe ser essa personagem e descobre que tem de viver numa constante procura da verdade e de si, cuja estabilidade identitária dependeria do encontrar de tal verdade. Mas ela furta-se numa constante mudança e Carlos procura-se também a si próprio nessa procura de uma verdade sempre adiada. Deixa, com isso, um vazio identitário na relação com a mulher (ele já não é o mesmo) que, por sua vez, estando habituada às dificuldades, se move bem nesse mundo de quase pobreza. Ela torna-se, então, a personagem forte, o que é complementado pela situação financeira e social do pai que acaba por comprar a fábrica do velho Bruno, realizando a dialética do Senhor e do Escravo que passa a senhor pelo seu trabalho. Tudo isto leva Carlos ao dilema paralisante de não saber quem é por não saber ser personagem deste contexto e por não encontrar uma verdade estável que lhe orientasse a ação e a reconstrução de si próprio:

Mas precisamente isso queimava, para Carlos, toda a razão de ser e de agir. Como abrir-se um homem a uma ideia, atirar-se a uma ação, se tudo era provisório? Como segurar a dignidade do homem, arrebatando-lhe a ilusão de que é definitivo? [...] que são os outros? eu? ${ }^{52}$

51 Escrever. Lisboa: Bertrand, 2001, n. ${ }^{\circ} 144$.

52 Mudança, pp. 117-118. 
Esta problemática ligada ao conflito Ideia/Ação vai ser o grande tema de Apelo da Noite. ${ }^{53}$ E, como disse atrás, a primeira certeza que a arquipersonagem terá no seu percurso ao longo das obras de Vergílio Ferreira será a aparição de si a si próprio.

Mas há um episódio em Mudança que costuma passar despercebido, e que é o caso da mulher que matou o marido, que voltou de África como se não tivesse envelhecido, e que Carlos vai defender em tribunal. Ora ela matou-o porque, tendo estado separados durante os quinze anos que ele passou em África, esperava que ele tivesse envelhecido como ela, o que, aparentemente, não aconteceu. Assim, esse homem que ela passou de novo a ter a seu lado não era o seu verdadeiro marido. Ele tinha voltado rico, sem amantes, e a mulher continuava a amá-lo. Mas matou-o.

Disse-me [explica Carlos a Berta]: matei-o porque ele não era o mesmo. [...] Ela não sabe explicar-se. Mas eu entendo-a. Quando se separaram, ambos eram novos. Ele usava certas palavras, certos gestos. Ela envelheceu, a vida mudou-a. Nos quinze anos, a mulher foi transformando a imagem do homem. De maneira que, ao vê-lo igual ao antigo, ela sentia-o à sua margem e julgava-o realmente um outro. Mas a lei dizia-lhe que aquele é que era o marido. Tinham filhos. E, para a lembrança dos filhos, aquele é que era também o pai. Mas na realidade o pai não era aquele. A mulher amava o homem que havia de vir e não veio. Tinha um pai para os filhos e impunham-lhe outro pai, mesmo os filhos. Então ela matou-o. foi assim. [...] Forçavam-na a casar com outro homem, matou-o. a mulher perguntou-me: que ia ser de mim daqui em diante? Penso que ela queria dizer: como vou casar-me cada dia com um homem que não muda, que me fica em cada dia mais longe, e diferente, por isso mesmo? E matou-o. ${ }^{54}$

Ou seja, matou o marido para não the ser infiel porque o marido não mudara e ela não o reconhecia na antiga identidade. Esta questão da identidade no tempo é importante em Vergílio Ferreira e liga-se às conceções existencialistas do tempo, depois de se ter ligado, em Mudança, ao movimento hegeliano para a realização do Espírito (Mudança é um romance hegeliano, como já referimos). Em Alegria Breve, ${ }^{55}$ há um episódio curioso, repetido no princípio e no fim do livro, e que refere o narrador a fazer amor com a mulher velha depois de se ter excitado com uma fotografia dela nova, o que faz a mulher chorar, como se ele a estivesse a trair com ela própria noutro tempo. A ek-sistência obriga a uma contínua recomposição do que se é, mantendo apenas o eu metafísico a função de assegurar a ipseidade para além dessas mudanças, o que a mulher que matou o marido não percebeu. É a oscilação

53 Lisboa: Portugália, 1963.

${ }^{54}$ O.c., pp. 189-190.

55 Lisboa: Portugália, 1965. 
entre o eu metafísico, raiz da ipseidade, e um eu que se faz no encontro com o tempo e que é mais radical que o eu psicológico.

Há outra história trágica, esta mais lembrada, sobre a transformação ou perda de uma determinada identidade social, fruto da personagem que se representou ou representa no jogo da vida, como Carlos de Mudança já tinha experimentado. É a história do Bailote, o "semeador bíblico" de Aparição que, quando o patrão lhe diz que ele envelheceu e já não tem essa mão funda que fizera a sua identidade de semeador excecional, que o distinguia e que era a única coisa positiva que tinha na vida para ser alguém diferenciado da massa, se enforca. Ele era uma personagem valorizada numa narrativa identitária que, subitamente, deixa de o caracterizar, o que mostra a necessidade do reconhecimento do outro para ser. O outro - patrão - que lhe construíra a narrativa identitária que o diferenciara e sobre a qual baseara a sua vida mudou essa narrativa e o Bailote, perdida a narrativa da sua identidade, perdeu a razão de viver porque deixou de ser. Deixou de existir numa ligação ao universo que se materializava pelo seu trabalho.

As questões da dimensão originária de si vão alargar-se, com Alegria Breve, ao próprio Homem e à narrativa cultural em que se constrói. Com efeito, a aldeia, que se esvazia e onde só ficaram os velhos que vão morrendo ao ponto de o narrador ficar sozinho, é símbolo de um mundo que acabou, o mundo do homem alienado de si pela entrega aos deuses, e o novo homem irá agora construir um novo mundo. Mas o novo homem terá que sair da geração seguinte, estando a atual ainda contaminada com o mundo antigo, sendo o narrador um homem de transição, à espera do filho que gerou a partir de uma relação triangular que é comparada à geração de um novo filho de Deus. No romance seguinte, Nítido Nulo, o filho, embora não se interesse pelo mundo humanizado que o pai pretendia criar, faz parte, de facto, de um novo mundo, mas um mundo de plástico, e, fundamental para a sua pertença a esse novo mundo, fala uma nova linguagem.

Vemos, assim, um Homem que é doador de sentido ao mundo ("e aqui um elo de ligação da fenomenologia com o existencialismo") ${ }^{56}$ dependendo esse mundo de uma linguagem que o diga. Esta é uma questão fundamental em Vergílio Ferreira, aparecendo mesmo a relação com a dimensão original da vida ligada à palavra que a diga. Em Aparição esclarece: "Escrevo para ser, escrevo para segurar nas minhas mãos inábeis o que fulgurou e morreu" 57 e isso que fulgurou e morreu, tem a ver, sobretudo, com a dimensão original de si, que lhe apareceu, mas também com a Presença ausente e com o que ela

56 "Da Fenomenologia a Sartre", cit., p. 27.

57 O.c., p.181. 
representa de encontro com a Face, a Verdade, a sombra que envolve o excesso de sentido em toda a doação de sentido, e que muitas vezes é significada pela névoa, nevoeiro, cegueira mesmo. A metáfora da bruma não deixa de lembrar Husserl (dado que em Heidegger se liga mais ao aborrecimento do quotidiano) e o horizonte brumoso sobre que o vivido da consciência se destaca. A Presença que a distância, a bruma e a dimensão radical da origem não deixam ver, e que se sente muitas vezes pairando como um espírito numa espécie de mundo paralelo, está à espera que a arquipersonagem diga a palavra fundamental que a trouxesse para a vida dos homens, palavra que o narrador de Para Sempre ${ }^{58}$ esperou que a mãe lhe dissesse ao morrer mas que, pelo menos, ele não conseguiu perceber. De resto, a mãe não tha poderia dizer porque enlouqueceu por 0 pai os ter abandonado perdendo, assim, a capacidade de bem discorrer.

A palavra fundamental que desse a cifra do universo não poderia ser dita por alguém sem amor porque um dos aspetos mais importantes da Presença é ser a Face original que os narradores esperam e que lhes traria o amor com a Mulher ausente fundamental, sempre para além das mulheres reais. Por isso, para se aproximar dela, em Rápida, a sombra, o narrador trata frequentemente a mulher amada por "mon amour" e diz mesmo: "Mon amour. My love. Não há línguas bastantes para te dizerem", ${ }^{59}$ marcando a necessidade de percorrer as línguas tal como as mulheres concretas (percurso de que Estrela Polar é um exemplo radical pela geminalidade das irmãs que as torna iguais) até ao encontro final com a Presença/Verdade. Essa procura/percurso aparece ao longo de toda a obra de Vergílio Ferreira de formas várias, necessitada pela fratura das personagens, como em $O$ Caminho Fica Longe (mas não só), até à oposição velha/nova, como na Helena/Hélia de Rápida, a sombra, ou na mulher que se sente traída consigo própria quando nova, o que é equivalente da geminalidade que é preciso esgotar. Esta necessidade de multiplicar as línguas que trariam a Presença para o presente do narrador aparece também na discreta alusão do Dr. Beirão de Cântico Final ${ }^{60}$ a uma antiga namorada que o deixou porque ele queria que ela aprendesse inglês, o que, no contexto da obra de Vergílio Ferreira, só pode significar que ela entendeu que não era a ela que o Dr. Beirão desejava mas a essa outra ausente, como a Aida de Estrela Polar percebeu quando Adalberto gritou o nome dela para a distância.

Convém, também, a propósito, referir as reuniões culturais e políticas de valor idêntico e igualmente desgastável de Rápida, a sombra, ou os valores equivalentes em Signo Sina ${ }^{61}$ que impedem a reconstrução da aldeia destruída

58 Lisboa: Bertrand, 1983.

${ }^{59}$ Lisboa: Arcádia, 1975, p. 191.

${ }^{60}$ Lisboa: Ulisseia, 1959.

61 Lisboa: Bertrand, 1979. 
pelo sismo por o próprio Arquiteto mostrar a equivalência desses valores, dado que é possível defender com iguais argumentos pôr no centro da aldeia a Igreja, o Tribunal, a Escola, bloqueando, assim, a decisão sobre a nova Forma da aldeia. Tudo isto são maneiras de referir a necessidade e ao mesmo tempo a impossibilidade de encontrar a origem, seja ela o valor original na sua radicalidade ou a Face que realmente os narradores amam para lá de todas as faces visíveis. Essa problemática persistente vai até ao livro de pensamentos que Vergílio Ferreira escrevia quando morreu, Escrever:

Se tu viesses. Porque tudo está preparado para a tua vinda. Os caminhos transbordam de flores silvestres, o sol ilumina-se como um lume novo. Virás decerto na aragem leve, fluida de ausência, a face triste. Ou talvez sorrias no teu alheamento como uma memória que passou. Trarás talvez no rosto o sinal de uma sagração com que os deuses te ungiram na eternidade. E haverá no ondeado do teu corpo o olhar com que te espero. Não tenho pressa, o que é grande e inimaginável leva milénios a acontecer. Eu estarei sentado à tua espera porque é impossível que não venhas quando a terra inteira se preparou para que passasses. Se tu viesses. Tu quem? ${ }^{62}$

Outro aspeto fundamental é a importância do sentimento que no universo imaginário de Vergílio Ferreira se liga à Presença como Amor e como Verdade. Por isso,

[...] o significado de qualquer palavra por onde a emoção humana passou, estende-se até ao infinito do indizível. [...] A língua faz-se com o mistério dela que é onde apenas pode caber o homem. E dois homens que conversam é com o indizivel que se entendem. ${ }^{63}$

A língua para dizer o indizível necessita do sentimento. E aqui uma divergência de Vergílio Ferreira com Husserl:

Portanto, Husserl perseguiu obstinadamente uma fundamentação decisiva e radical para o pensar. [...] E vimos como na Lógica afirma claramente o distanciamento infinito para a verdade absoluta. Seria, no entanto, de admitir que, na sua recusa do "sentimento" que distingue o seu conceito de "evidência", ele nos prevenisse contra a mais genérica objeção de que uma escolha da sua racional radicalidade, ou puramente da razão, é de si não racional. [...] Porque o mais importante e interessante para o homem não se situa na radicalização de um pensar, mas no que pensa esse pensar. Quando a fenomenologia acaba, é que a vida importante começa. E isso foi o que sentiu o existencialismo de um Jaspers ou o pensar existencial de um Heidegger. [...] [Husserl] purifica drasticamente a sua reflexão do que pode contaminar-se de "sentimento". Só que, e para lá

62 Escrever, n. ${ }^{\circ} 94$.

${ }^{63}$ Ibid., n. ${ }^{\circ} 44$. 
da opção da radicalidade do pensar, o que com esse pensar pensamos é na sua maior parte decidido não por uma "pureza" do pensamento, mas pelo que releva do que chamaríamos "sentir". ${ }^{64}$

Ao longo de toda a sua obra, Vergílio Ferreira irá afirmando que as verdades fundamentais da vida se decidem numa parte de nós que é prévia ao pensamento racional e que se situa numa zona de sentimento a que as verdades existenciais dão acesso, precisamente pelo sentimento. Daí também o seu interesse pela Stimmung de Heidegger. E como a finalidade do pensar é, para Vergílio Ferreira e para a fenomenologia e o existencialismo, o recuperar a dimensão radical da origem, uma vez que isso se atinge, para Vergilio Ferreira, por um pensamento que depende do sentimento enquanto determinador daquilo por que o pensamento se interessa, as verdades existenciais são o verdadeiro motor do que fazemos ou pensamos. Nomeadamente, é nelas que a arte se baseia para dar acesso ao que chama "o mundo original", mundo onde o homem encontra a radicalidade de si e de que a arte é a forma privilegiada de a atingir.

Também quando pensamos ou quando nos interessamos por uma doutrina,

[...] quando a iluminação se abre, quando uma doutrina nos atinge, ela é o nosso modo de ser, ela é a nossa pessoa. Então, o que resta do sistema, da orgânica mental, é um protocolo de razões, um exército de palavras que não detém nunca a sorte do combate: a decisão de uma tal luta está na obscuridade de nós, das nossas ignoradas raizes. ${ }^{65}$

Vemos, assim, a importância de tentar entender aquilo a que chamei o "mito estilo", a Forma interior que é a verdadeira autora de um pensar.

Além disso, a adesão de Vergílio Ferreira à variante existencialista da Fenomenologia baseia-se também nisso, no atingir a radicalidade da vida pelo sentimento. "Assim, poderíamos talvez dizer que toda a doutrina é existencial, mesmo a «materialista», desde que a vivamos dentro de nós". ${ }^{6}$

É a mesma tentativa de tocar a radicalidade da vida e de a fixar através da palavra que percorre todo o romance Para Sempre, onde o narrador foi diretor da Biblioteca Pública e interroga-se sobre que é que resta de todos os livros que compõem as bibliotecas quando se pretende conhecer a Verdade original, dado que todos são equivalentes nas teorias culturais que se percorrem para apenas se superarem e que, ao aderirmos a alguma delas sabemos que

\footnotetext{
64 "Do indivíduo à História-Husserl", pp. 297-299.

65 "Arte, Verdade", p. 186.

66 "Da Fenomenologia a Sartre," p. 108.
} 
é uma adesão provisória porque se desgastará, tal como as outras. É a procura dessa verdade através da palavra fundamental que a dissesse que o diretor reformado da Biblioteca vai perseguir ao recordar a vida, antes de morrer. O romance é introduzido por dois versos de Saúl Dias: "A vida inteira para dizer uma palavra! / Felizes os que chegam a dizer uma palavra!'. E, ao longo dele, como de vários outros, há muitas páginas dedicadas à palavra:

Não haverá então uma palavra que perdure e me exprima todo para a vida inteira? [...] Uma palavra. A primeira que em toda a minha vida me esgotou o ser. A que foi tão completa e absorvente, que tudo o mais foi um excesso na criação. Deus esgotou em mim, na minha boca, todo o prodígio do seu poder. Ao princípio era a palavra. Eu o soube. E nada mais houve depois dela. ${ }^{67}$

Essa palavra recriaria o mundo original e é função da arte procurar dizê-la.

\section{III}

Façamos, agora, um breve percurso pelos ensaios, dado que os restantes romances não trazem nada de novo para o tema que aqui nos interessa, ensaios de que já fomos falando dado que a ficção de Vergílio Ferreira põe, sobretudo, em jogo ideias, tal como a de Dostoievsky, dando-lhes vida pelo sentimento, característica fundamental da arte, como sabemos.

Para além da declaração já mencionada da importância que retrospetivamente Vergílio Ferreira reconhece à Fenomenologia como inseminadora das ideias que põe em romance, o primeiro volume de Espaço do Invisível abre com uma epígrafe de Merleau-Ponty, tirada de Le Visible et l'Invisible: “[...] peut-être que la réalité n'appartient définitivement à aucune perception particulière [...] ele est toujours plus loin". É o homem que é sursis e ek-sistência mas, no contexto vergiliano, é também o homem que procura a Origem de si na verdade que dará a cifra da vida, que a palavra original dirá, e que fará encontrar a Presença ausente. E é o homem que procura reduzir a vida à sua radicalidade, homem que se constrói no encontro de si e do mundo, como mostra, também, a ligação do encontro da Presença e do encontro da dimensão metafísica de si ao universo através da fusão que $E m$ Nome da Terra tão liricamente exprime nas belas páginas finais atrás citadas. O que, como vimos, já estava implicado no conceito de "aparição", dado que a aparição de si a si próprio se faz num momento auroral e infinitesimal de uma diferenciação que guarda a presença de um todo que não deixa de ser ameaça de fazê-lo cair numa fusionalidade anterior à diferenciação. 
Vemos, ao longo dos cinco volumes de Espaço do Invisivel, um percurso por temas diversos, leituras circunstanciais de obras, mas, sobretudo, os artigos importantes neles recolhidos são momentos em que o autor se confronta com algumas correntes do pensamento contemporâneo e, sobretudo, com o existencialismo e a fenomenologia. Insistindo na valorização do sentimento que o existencialismo trouxe, refere, também, a esse propósito:

A fenomenologia, pois, restitui o homem a todas as construções "objetivas" e, fazendo-o, restitui-lhes o sangue, o calor das mãos, a capacidade de nos admirarmos - o que é para Platão e Aristóteles a raiz da Filosofia e para Heidegger razão da sua vitalidade constante. Eis porque, imprevistamente, nós descobrimos que ela aproxima o pensar do sentir, que ela trouxe a arte para um domínio do conhecer. $^{68}$

A fenomenologia animou "de sangue quente" a literatura. ${ }^{69}$ Não podemos deixar de notar que a tónica aqui é um pouco diferente da citação anterior, o que não é propriamente contraditório, citação em que mencionava o desinteresse de Husserl pelo sentimento, estando agora Vergílio Ferreira a referir-se a esta consequência do pensamento fenomenológico.

É todo um esforço para apoiar teoricamente "verdades do sangue" que são anteriores às doutrinas em que se suportam e onde sobressai a procura, através do sentimento, de uma origem perdida ("O incognoscível [...] não tem nome e habita no coração do homem").$^{70}$ Esforço que dará acesso, quando usado pela arte, ao mundo original que todo o pensamento de Vergílio Ferreira sempre procurou e ao outro original (Presença) que, se encontrado, fixaria a identidade metafísica da arquipersonagem, fazendo coincidir o em-si e o para-si, e de que as páginas finais de Em Nome da Terra, insisto, representam a, finalmente, conseguida realização disso, não esquecendo nós que a Presença assim encontrada nesse romance tem a ver com a mulher morta e recriada pela escrita na sua dimensão fundamental. A ficção de Vergílio Ferreira representa, assim, um caminhar bem sucedido, de tipo heroico, como pretendi mostrar em $O$ Universo Imaginário de Vergílio Ferreira. ${ }^{71} \mathrm{O}$ encontro com a Presença representa o sucesso da procura do invisível: "Há uma vida invisível atrás da vida visível e é naquela que esta se esclarece". ${ }^{72}$

68 "Da Fenomenologia a Sartre", p. 53.

${ }^{69}$ Ibid., p. 53.

70 Espaço do Invisivel 1, p. 9.

71 Vd. a Conclusão, pp. 283-291.

72 "Questionação a Foucault e a algum estruturalismo". Espaço do Invisivel 3. Lisboa: Arcádia, 1977, pp. 261-304, p. 298. 
Invocação ao meu corpo ${ }^{73}$ e Carta ao Futuro $^{74}$ são os ensaios mais "livres" e onde Vergílio Ferreira mais realiza o ensaio poético. Invocação ao Meu Corpo está cheio de referências à fenomenologia, muitas vezes através de Merleau-Ponty mas interessa aqui apenas insistir sobre as reflexões sobre a palavra e a sua importância na construção intencional do sentido. Por exemplo:

De ti às coisas a palavra é a luz, a claridade absoluta que te enche o caminho. [...] A realidade é um monturo e a confusão a que nós impusemos uma ordem. [...] Termo de correlação, o real, com ser um monturo, não deixa de limitar as possibilidades de o ordenar, e assim ele existe nessa ordenação, sendo todavia para mim a ordenação que eu the der. A realidade "é" a palavra em que a digo; mas se outra palavra a pode dizer, é porque ela the preexiste como limite de possibilidades. A palavra é a leitura do mundo, não a leitura de $s i .^{75}$

Invocação ao Meu Corpo foi escrito ao mesmo tempo que Alegria Breve e insiste, também, sobre a renovação do homem e do mundo (para a qual a palavra é instrumento imprescindível). E aí a referência, logo na página inicial, a Deucalião, e, logo na seguinte, à "urgência de um mundo a repovoar"; 76 "o que eu trago em mim é o anúncio do fim do mundo, ou mais longe, e decerto, o da sua recriação". ${ }^{77}$ E notemos como tudo isto se liga à Presença:

Mas o aceno que vem da infinitude estende-se a tudo quanto na vida guarda o sinal do indizível. Obscura névoa, opaca e muda, ubíqua e terrivelmente presente, aí mora a origem e o absoluto, a súbita comoção do anúncio suspenso, o terror hiante, a alegria absurda e enorme, quente como um choro imóvel. Etéreo fluido de uma inquietante presença, como a aura desta noite total que é só presença no frémito de eu estar aqui e olhar. ${ }^{78}$

Ou:

Espírito informe de uma fugitiva presença, luz incerta que se acende por dentro do que é iluminado, invisível realidade visível, é quando vem a ti o raro privilégio de assistires ao encontro desse espírito e do que o manifesta, é quando o visível e o verificável se encontram com o que se furta à nossa verificação e visibilidade, é então que a verdade se incendeia de fulgor, o belo de beleza. ${ }^{79}$

Essa "fugitiva presença" é, juntamente com a aparição do eu metafísico e toda a problemática ligada ao tu e à incomunicabilidade, que só resolvida

${ }^{73}$ Lisboa: Portugália, 1969.

${ }^{74}$ Lisboa: Portugália, 1958.

${ }^{75}$ O.c., pp. 332-333.

76 O.c., pp. 11-12.

77 Ibid., p. 13.

${ }^{78}$ Ibid., p. 23 (sublinhado por mim).

${ }^{79}$ Ibid., p. 52 (sublinhado por mim). 
num terceiro (essa mesma Presença, como vimos), a marca mais constante do encontro com a origem, com a radicalidade das coisas. Isso será possível depois de encontrar a palavra de onde tenham sido limpas todas as sedimentações para poder significar a origem. Significar a origem é a pretensão que marca todo o percurso da obra ficcional e ensaística de Vergilio Ferreira ("Assim o que relembro [de uma memória antiga, de um passado original] não tem face nem nome, é a forma oca de um limiar indistinto, pura anunciação de presença, obscuro alarme de uma aparição". $)^{80}$ Os seus dois livros de Pensamentos, Pensar e Escrever repetem-nos e desenvolvem-nos em contextos diversos.

\section{IV}

Resta-nos perguntar se a obra de Vergílio Ferreira nos dá elementos para entendermos o fundo não-racional onde radicam as verdades existenciais, "do sangue", que orientam a nossa adesão às verdades racionais, um tema que percorre toda a sua obra:

Porque há um lugar ignoto, no abismo de nós, que é onde a verdade se gera, e a fórmula da racionalidade é o eco presente dessa irrealidade ausente. ${ }^{81}$

Ou:

Mas à tua reação [...] jamais lhe saberás a origem porque a sua origem é a origem de ti - e tu não tens origens. [...] Eis porque em rigor não há verdades indiferentes [...] um Heidegger mo ensinou com a doutrina da Stimmung e um Scheler, ao aviso, aliás, já antigo de Pascal. ${ }^{82}$

Porque nós vivemos de acordo com o impensado que é a dimensão pessoal do excesso de sentido que o indizível manifesta e que não deixa de ter algum parentesco com o Ser de Heidegger. Por isso, também:

A Fenomenologia acentua-nos ainda - e este é, para o que nos interessa, o seu aspeto mais importante - que é em cada um de nós que se decide verdadeiramente até mesmo um axioma matemático, que não há Substância única alguma - uma possível intersubjetividade não supera, a rigor, o nível estritamente mental - que o indivíduo não é uma "inessencialidade" hegeliana, subsumível por qualquer forma de eficácia totalitária, que o homem é, no "reino" da criação, não apenas o "rei", mas largamente o verdadeiro criador.

${ }^{80}$ Carta ao Futuro, p. 19.

81 Invocação ao Meu Corpo, p. 117.

${ }^{82}$ Ibid., pp. 118-119. Vd., também, todo o capítulo "Do impensável" que inaugura Pensar:

83 "Da Fenomenologia a Sartre", p. 54. 
Esse um dos aspetos da importância de "Husserl [que] envolve na análise da vivência uma relação com o impensado". ${ }^{84}$

Ora, a obra de Vergílio Ferreira tem um núcleo de coerência, como em princípio todas as obras devem ter, mas que é particularmente forte e visível. Nos anos sessenta, Ch. Mauron falava das metáforas obsidiantes que nos fazem chegar à psicologia de um autor materializada no que ele chamava "o mito pessoal". ${ }^{85}$ Não pretendo, pela minha parte, chegar à psicologia de Vergílio Ferreira que nem sequer me interessaria analisar. Pretendo, apenas, mostrar um núcleo de autoria da sua obra, uma Forma que a obriga a seguir caminhos e interesses cuja coerência, por ser significativa e necessitar de estabelecer conexões lógicas, se organiza numa narrativa fundadora, um mito pessoal, poderíamos dizer, embora partindo de pressupostos e visando objectivos diferentes dos de Mauron, e a que chamei, como já disse, de mito estilo. ${ }^{86}$

Já os Poemas de adolescência e juventude se organizavam "em torno de uma Ausência que remete para um Paraíso perdido, além do Tempo e do Espaço, e de uma Queda, decorrente dessa Ausência. É, com efeito, a Ausência de uma Pessoa Fundamental, Verdade ou Caminho onde o encontro fosse possível, que provocou a queda atual no poço de águas mortas e lodosas, onde o Presente é vivido," como escrevi num estudo que lhes dediquei há muitos anos. ${ }^{87} \mathrm{O}$ espaço em que o poeta se move é deserto, sem Geometria que traçasse caminhos, e o pai não ensina o caminho para esse lugar mítico onde poderia reencontrar a Pessoa fundamental. No poema "O Filho Pródigo" lê-se: "o meu regresso não deixo festejar, / nem quero que me vão matar vitelos, / nem que me vistam fatos dos mais belos, / enquanto o Pai me não disser: «meu filho, / eis o teu trilho!»" Poderíamos pensar que a maiúscula indica o Pai Celeste que não o ilumina (na altura era ainda crente) mas a desvalorização do pai, que não indica o caminho, é fraco e, eventualmente, nem sequer é o verdadeiro progenitor, como em Estrela Polar, ou que está ausente muitas vezes por morte, como notou Eduardo Lourenço (ausência com algumas variantes como o facto de o pai civil do filho do narrador de Alegria Breve não ser o seu pai natural) parece indicar que o pai terrestre não pode ser excluído dessa negatividade. Essa ausência e desvalorização vai ser aproveitada, como em Alegria Breve, para um nascimento à maneira de Cristo (o velho marido de Vanda será o pai adotivo, civil, do filho do narrador), sendo este filho o

84 “Questionação a Foucault", p. 271.

85 Des métaphores obsédantes au mythe personnel, Introduction à la Psychocritique. Paris: José Corti, 1963.

86 Vd. O Mito e o Estilo. Lisboa: Presença, 1982.

87 "Uma leitura dos Poemas inéditos de Vergílio Ferreira", Estudos sobre Vergílio Ferreira, ed. cit., pp. 389-398. 
novo deus que instaurará a divindade do novo homem. E vai-se prolongar por algum desinteresse ou agressão dos filhos em relação aos pais, sobretudo nos romances a partir de Nítido Nulo.

Ainda nesses Poemas de juventude, a estrela aparece já como metáfora do mundo original e da pessoa fundamental que habita esse mundo. Ou seja, a temática que, consistentemente, percorrerá toda a obra de Vergílio Ferreira, nomeadamente a procura da origem, da verdadeira identidade metafísica, da criação de um novo homem, da afirmação que a identidade metafísica não deriva dos pais ("nenhum homem tem pais"), tudo isso parte de uma situação pessoal que se baseou, biograficamente, nas ausências que marcaram a infância por o pai ter levado a mãe e a irmã para os Estados Unidos quando ele tinha $2 / 3$ anos e, facto também importante, na ausência da namorada que morreu de tísica galopante em dois meses quando estavam na Faculdade, e que a Sandra de Para Sempre e a Oriana de Até ao $\mathrm{fim}^{88}$ imortalizam e de que a Presença ausente na sua dimensão de Face é a expressão mais recorrente.

Vemos, assim, que um fundo biográfico se transforma numa narrativa fundadora da identidade intelectual do autor (quer de ficcionista quer de ensaísta) e que a Cultura (sistemas literários, políticos ou filosóficos) vai recobrir e ser informada por ela. Reconhecemos, a partir dela, o interesse pela intencionalidade fenomenológica que põe em relação um eu e uma realidade que se criam mutuamente, unindo, assim, as margens da Disjunção entre este mundo vazio e o mundo da Presença, porque a fenomenologia implica também a procura das essências e da origem metafísica de si que a narrativa fundadora das consistências da obra de Vergílio Ferreira sempre procurou. Além disso, toda a questionação do encontro ou da incomunicabilidade com o outro, que Estrela Polar ilustra, se molda nesta antiquíssima problemática vergiliana (desde os Poemas da juventude) e as hesitações, que referi, entre a importância do tu na criação do eu e a afirmada anterioridade deste se moldam também neste desejo/impossibilidade de um encontro que a narrativa fundadora que marca o mito estilo transformou em impossibilidade. Mas, apesar dessas hesitações, não deixa de dizer, no estudo que dedica à fenomenologia e ao existencialismo, que "a glória do que somos concretamente foi o outro que connosco a conquistou". ${ }^{89} \mathrm{O}$ anseio do Outro (da Outra) que se distanciou para o além da Presença ausente é apenas colmatado em Em Nome da Terra, insisto, levando à fusão com o universo, dado que na distância do universo é que habita a Presença, muitas vezes simbolizada pela estrela, nomeadamente polar, e em Até ao Fim, onde o narrador desiste de continuar a procurar Oriana e se ins-

88 Lisboa: Bertrand, 1987.

89 "Da Fenomenologia a Sartre", p. 105. 
tala inteiro no Presente, graças à nova mulher, Clara, que sabe a palavra que afasta os mortos e o passado: "Clara sabe a palavra exata para todo o presente ser meu".90

Esta questão da Forma interior que multiplica ad eternum a narrativa fundadora não pode ser aqui desenvolvida mas creio que o que dela referi chega para mostrar a implicação da vida e das escolhas culturais, implicação que a própria obra de Vergílio Ferreira diz. ${ }^{91}$ Lembremos a insistência nas verdades existenciais, do sangue, que são as que movem a razão aquém de toda a racionalidade, e que o sentimento manifesta, sobre que ao longo de toda a obra teórica ou ficcional Vergílio Ferreira insiste e que são uma das coisas que the interessam no existencialismo, que assim deu um suporte teórico a esse consciência de que é o indizível que move o dizível, em que o futuro e o passado se encontram num presente que irradia para o passado e o futuro. Como diz ainda no artigo "Do indivíduo à História - Husserl", referindo-se à adesão às verdades gerais, nomeadamente aos juízos do gosto:

Mas estas são verdades que se incluem na generalidade das verdades humanas para cá do radicalismo racional e que se decidem pelo equilibrio interno de nós, gerado não sabemos onde nem como, mas que se nos impõe sem discussão. ${ }^{92}$

Uma última palavra a propósito da importância de Hegel para um Vergílio Ferreira que em 1973, na entrevista que referimos, declarou que era fundamentalmente um hegeliano. Mais tarde, como também vimos, percebeu a importância de Husserl na formulação da sua própria problemática, ele o afirmou. A citação com que termino este trabalho mostra como Vergílio Ferreira não desistiu de fazer a ponte com o seu passado:

Hegel [...] domina hoje imensamente o pensamento europeu. Com efeito, excetuados os positivistas lógicos e os neo-realistas como um Russell, que diz mal dele, Hegel não só inspira a estrutura formal da dialética materialista e histórica, como está presente em larga medida no Existencialismo, nomeadamente em Jean-Paul Sartre que à Fenomenologia do Espirito vai buscar não apenas alguma terminologia (como o pour-soi que é a consciência, e o en-soi que é a coisa) mas também muitas e muitas das suas conceções [...] Se agora passássemos para o domínio específico da Fenomenologia de Husserl, que é um dos instrumentos capitais da realização do Existencialismo, nós veríamos ainda muitos pontos de coincidência com a Fenomenologia do Espirito de Hegel.

90 O.c., p. 272. Ver também o meu estudo "Até ao Fim, de Vergilio Ferreira". In: Petar Petrov, O Romance Português pós-25 de Abril. Lisboa: Roma Editora, 2005, pp. 95-104 (sublinhado por mim).

$91 V d$. a Conclusão do meu Universo Imaginário de Vergilio Ferreira, que já referi, e o meu estudo "O mito estilo de Vergílio Ferreira." Colóquio Letras, 103 (1988): 72-74.

92 O.c., p. 299 (sublinhado por mim). 
Assim, o conceito de "verdade" que é pura conquista, a afirmação de que uma coisa são os seus fenómenos e não existe pois o fantasma kantiano da "coisa em si" (que seria o que uma coisa é para lá do que a manifesta) e paralelamente uma certa absolutização da vivência, ou seja do que do mundo em nós persiste como representação, etc". ${ }^{93}$

\begin{abstract}
This study covers Vergílio Ferreira's fiction and essays to show the importance that phenomenology had in both. Vergilio Ferreira even declares at a certain point in his literary and essayist trajectory that the influence of Husserl's phenomenology was large in his work and especially noticed retrospectively. He who for a long period declared himself a Hegelian who had moved on to existentialism via unhappy consciousness will link Hegel to Husserl's phenomenology revealing a trajectory justifying the coherence of his work.
\end{abstract}

93 "Existencialismo e literatura". Espaço do Invisivel 2, ed. cit., pp. 23-55, pp. 29-31. Sobre a presença da Fenomenologia e, nomeadamente de Hegel, na obra de Vergílio Ferreira, ver também a dissertação entregue para doutoramento de Luís Miguel Taveira Lourenço, Uma leitura fenomenológica de Vergílio Ferreira, Lisboa: UNL, 2012 (policopiado). 